\title{
Ofte feil termindato for jentebarn
}

\section{$\AA$ fastsette svangerskapslengden ut fra rutineultralydundersøkelse kan medføre økt risiko for dødfødsel hos jentebarn født etter termin.}

Bestemmelse av graviditetens lengde ved hjelp av ultralyd forutsetter at fostrene er like store ved tidspunktet for undersøkelsen, som som regel finner sted i graviditetsuke 17-19. Nå har svenske forskere undersøkt om ultralydfastsettelse av terminen medfører ulik risiko hos de to kjønn for alvorlige perinatale utfall relatert til overtidighet (1).

Data fra det svenske fødselsregisteret for nyfødte i perioden 1973-78 ble sammenliknet med data for perioden 1995-2007. I den første perioden var svangerskaps- lengden basert på dato for siste menstruasjon, i den andre var den fastsatt ved hjelp av ultralyd. I første periode var det lavere risiko for alvorlige perinatale utfall for jenter født etter termin enn for gutter. Etter innføring av ultralydfastsettelse var det for jenter født overtidig høyere risiko for dødfødsel (OR 1,60; $95 \%$ KI 1,11-2,30) og mekoniumaspirasjon $(1,39 ; 1,10-1,75)$ enn for gutter.

- Resultatene kan tyde på at termindatoen ved rutineultralydundersøkelsen ikke sjelden fastsettes til et senere tidspunkt dersom fosteret er jente enn når det er gutt. Det er fordi jentefostre ofte er mindre, sier gynekolog Erling Ekerhovd i Trondheim. - Etter graviditetsuke 42 er risikoen for intrauterin fosterdød generelt ca. 1:500.

Ifølge forskerne skyldtes omtrent en tredel av dødsfall blant jentebarn ved over- tidig graviditet at ultralydterminen var fastsatt til et for sent tidspunkt. Studien er derfor av stor klinisk interesse, sier Ekerhovd.

\section{Trine B. Haugen}

trine.b.haugen@hf.hio.no

Tidsskriftet

\section{Litteratur}

1. Skalkidou A, Kieler H, Stephansson O et al. Ultrasound pregnancy dating leads to biased perinatal morbidity and neonatal mortality among postterm-born girls. Epidemiology 2010; doi: 10.1097/ EDE.0b013e3181f3a660.

\section{Sigarettrøyk hemmer degradering av kjemoattraktant}

Kronisk nøytrofil inflammasjon, som forårsaker omfattende vevsskade, er observert ved kronisk obstruktiv lungesykdom (kols). Den nøytrofile kjemoattraktanten prolinglysinprolin (PGP) er biomarkør for sykdommen. Nå har forskere fra USA og England undersøkt hvordan henholdsvis akutt nøytrofil lungeinflammasjon og sigarettrøyk påvirker PGP-nivåene (Science 2010; 330: 90-4).

Influensainfeksjon hos mus utløser en akutt nøytrofil inflammasjon. Forskerne fant at PGP ble degradert av leukotrien $\mathrm{A}_{4}$ hydrolase ved en slik infeksjon. Sigarettrøyk, derimot, hemmet aminopeptidaseaktiviteten til dette enzymet, noe som førte til akkumulering av PGP og nøytrofile. Dette kan forklare tilstedeværelsen av nøytrofile i lungene ved kols, som i hovedsak er forårsaket av røyking.

\section{Hepatitt B-infeksjon og non-Hodgkins lymfom}

Pasienter med kronisk hepatitt B-infeksjon får hyppigere enn andre non-Hodgkins lymfom. Det viser en kohortstudie med over 600000 sørkoreanske arbeidere og deres familiemedlemmer (Lancet Oncol 2010; 11: 827-34). Resultatene kan tyde på at kronisk hepatitt Binfeksjon kan fremme lymfomagenese.

53000 deltakere ( $9 \%$ ) hadde kronisk hepatitt $\mathrm{B}$, definert ved $\mathrm{HBsAg}$-positivitet. Oppfølgingspeioden var årene 1992-2006, og insidensen av hematologiske diagnoser ble gjort opp etter registrerte sykehusdiagnoser. $133 \mathrm{HBsAg-positive} \mathrm{og} 905 \mathrm{HBsAg-}$ negative deltakere utviklet non-Hodgkins lymfom (hasardratio 1,74).

\section{Testosteron og seksuell dysfunksjon hos eldre menn}

\section{Lave testosteronnivåer hos eldre menn er assosiert med seksuell dysfunksjon og fysisk kraftløshet.}

Den kliniske betydningen av lave testosteronverdier hos eldre menn er omdiskutert. Likevel får flere og flere substitusjonsbehandling med testosteron.

I en studie med ca. 3300 menn i alderen 40-79 år i åtte europeiske land ble sammenhengen mellom kliniske symptomer og testosteronnivå undersøkt (1). Fallende testosteronverdier var assosiert med manglende morgenereksjon, nedsatt libido og erektil dysfunksjon samt fysisk kraftløshet. Sent innsettende hypogonadisme ble definert som tilstedeværelse av minst de tre seksuelle symptomene samtidig med totalt testosteronnivå $<11 \mathrm{nmol} / \mathrm{l}$ og nivå av fritt testosteron $<220 \mathrm{pmol} / \mathrm{l}$.

- Denne studien bidrar med ny kunnskap, sier professor Trine B. Haugen ved Avdeling for helsefag, Høgskolen i Oslo. - Dagens diagnosekriterier for sent innsettende hypogonadisme er mangelfulle, derfor er det viktig med slike studier for å motvirke overdiagnostisering og overbehandling av aldrende menn. Vi vet lite om bivirkninger av substitusjonsbehandling med testosteron på bl.a. prostata og hjerteog karsystemet.

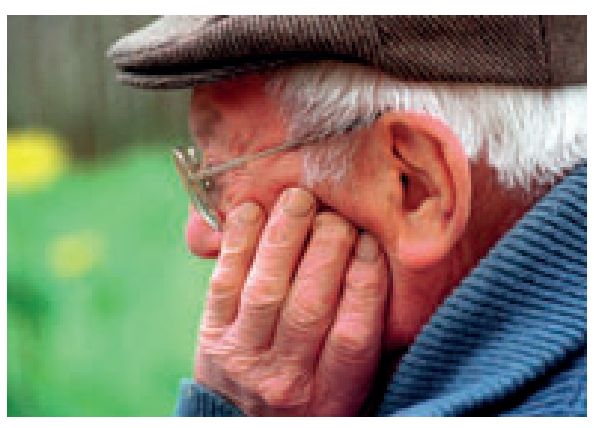

Illustrasjonsfoto Colourbox

$25 \%$ av mennene med normale testosteronnivåer hadde liknende seksuelle symptomer som dem med lave testosteronnivåer. Diagnosen sent innsettende hypogonadisme kan derfor ikke stilles på grunnlag av symptomer alene.

Det er verdt å merke seg at denne studien ikke angir kriterier for å starte substitusjonsbehandling hos eldre menn, sier Haugen.

\section{Geir Jacobsen}

geir.jacobsen@ntnu.no

Tidsskriftet

\section{Litteratur}

1. Wu FC, Tajar A, Beynon JM et al. Identification of late-onset hypogonadism in middle-aged and elderly men. N Engl J Med 2010; 363: 123-35. 